\title{
Book Review Essay: Capital Resurgent? The Political Economy of Gérard Duménil and Dominique Lévy
}

\author{
Matthew Nichter \\ Department of Sociology \\ University of Wisconsin-Madison \\ mnichter@ssc.wisc.edu
}

Duménil, Gérard and Dominique Lévy. 2004. Capital Resurgent: Roots of the Neoliberal Revolution. Cambridge, MA: Harvard University Press. 256 pages, ISBN-13: 978-0-674-01158-8 (\$59.00).

Written from a broadly Marxist perspective, Capital Resurgent proposes a sweeping interpretation of nearly one hundred and fifty years of capitalist development, illuminating the 'neoliberal revolution' of the past quarter century through comparisons with earlier periods. French economists Gérard Duménil and Dominique Lévy have produced an ambitious book, replete with useful data and provocative hypotheses, that summarizes and synthesizes their growing oeuvre.

At the center of their story is the rate of profit: the return on capital investment. Reinforcing the findings of Robert Brenner (1998, 2002a) and others (e.g. Armstrong, Glyn and Harrison 1991; Chan-Lee and Sutch 1985; Poletayev 1992; Shaikh 1999; Webber and Rigby 1996; Weisskopf 1992), Duménil and Lévy show that the 'golden age' of post-World War II prosperity in the U.S. and Europe ${ }^{1}$ depended upon high profit rates, which permitted rapid capital accumulation and stable employment. As profit rates declined during the late 1960s, 1970s, and early 1980 s - by about 45 percent, according to the authors' calculations - investment slowed, unemployment rose, and governments faced chronic budgetary problems.

Duménil and Lévy argue that the most important cause of the declining rate of profit in both the U.S. and Europe during this period was stagnant productivity. Between the mid-1960s and early 1980s, capital productivity (output per dollar of fixed capital investment) declined by about 30 percent. Though hourly labor compensation increased relatively slowly, labor productivity (output per hour of labor) increased even more slowly, resulting in a decline in the profit share (profit per dollar of output) of about 25 percent. $^{2}$

${ }^{1}$ Throughout most of the book, data on three countries - Britain, Germany, and France - is aggregated and treated as representative of Europe as a whole. More problematic is the paucity of data on Japan and other major Asian economies.

2 The mathematical relationships among the abovementioned variables are as follows: rate of profit $=$ capital productivity X profit share; profit share $=1$ - (hourly labor compensation / labor productivity). For the purposes of these calculations, profit is measured gross of interest payments and taxes. 
Based on an original data series they have compiled, Duménil and Lévy distinguish several major phases in the evolution of American capitalism since the Civil War. Over the very long run, the profit share in the U.S. has remained quite stable, so profit rate trends have tracked capital productivity trends. The first phase, extending from roughly the $1870 \mathrm{~s}$ through the $1900 \mathrm{~s}$, was characterized by falling capital productivity and profit rates. The second phase, stretching from roughly the 1910s through the 1950s, was characterized by rising capital productivity and profit rates. The third phase, spanning roughly the mid-1960s through the early 1980s, witnessed falling capital productivity and profit rates, much like the first period. Finally, it appears that a fourth phase, reversing the negative trends of the third, has already begun.

Duménil and Lévy posit that capitalist economies have difficulty sustaining rapid productivity growth. As a result, when labor costs rise and firms attempt to economize on labor, increases in labor productivity are likely to be offset by decreases in capital productivity, dragging the profit rate down. ${ }^{3}$ This pattern corresponds to the aforementioned first and third phases. But while slow productivity growth is the norm, waves of radical, interrelated innovations - in firm structure, production technologies, and the labor process - periodically occur, raising productivity and profit rates significantly. In the second phase, the authors identify several key innovations that played this role, including the improvement of accounting and forecasting techniques and the adoption of assembly line production methods. They link these advances to the growing prevalence of the modern corporation, in which owners delegate managerial responsibilities to a bureaucracy of salaried professionals (Chandler 1977). They attribute the apparent rise in capital productivity over the past two decades to the ongoing information revolution.'

There are several problems with the analysis described above. Firstly, the authors' explanation of productivity slowdown is underdeveloped. They briefly mention the following free-rider problem, which is a staple of mainstream economics: innovation typically requires costly investment in research and development, but ideas readily diffuse; competing firms can

The inverse of capital productivity is roughly comparable to Marx's 'organic composition of capital.' See Duménil and Lévy (2002a) for time series data on the latter. The profit share (or its close cousin, the ratio of profits to labor compensation) is sometimes treated as a proxy for Marx's 'rate of exploitation' of workers (e.g. Duménil and Lévy 2002a; Wolff 2003), but this operationalization has been heavily criticized (Shaikh 1978; Shaikh and Tonak 1994:Ch. 5; Moseley 1991:Chs. 3-4); I return to this issue below.

${ }^{3}$ Duménil and Lévy portray their explanation of falling profit rates as a refinement of Marx's 'law of the tendency of the rate of profit to fall.' But there are important differences. Duménil and Lévy reject the key causal mechanism in Marx's analysis. (This is only implicit in the book, but see e.g. Duménil and Lévy (2003a), which maintains that Marx's argumentation was logically flawed. For a refutation of this view, see Kliman (1996).) In their formal models, it is not the substitution of capital for labor per se that causes the rate of profit to fall. Rather, as suggested above, the culprit is a rate of total-factor productivity growth insufficient to fully offset the negative impact of rising hourly labor compensation (Duménil and Lévy 1995 and 2003a). Unlike Marx's explanation of declining profit rates, Duménil and Lévy's alternative does not assume the validity of the labor theory of value, though Duménil has elsewhere (1983-4) defended the latter; see also Duménil and Lévy (1989 and 2000:142). 


\section{JOURNAL OF WORLD-SYSTEMS RESEARCH}

therefore expect to reap the benefits of each others' research gratis, which undermines their willingness to make the necessary investments. The upshot is that competitive markets systematically underinvest in R\&D (Arrow 1959). Unfortunately, the authors do not present data on long-run trends in $\mathrm{R} \& \mathrm{D}$ expenditures. A cursory examination of trends in the volume of patent applications does reveal a demonstrable slowdown in the third phase and a surge in the fourth; however, for earlier years the data do not correspond as neatly to Duménil and Lévy's periodization (United States Patent and Trademark Office 2008). Nor do the authors examine trends in variables that might be expected to affect R\&D investment levels, such as the degree of product market competition, the intellectual property rights regime, government funding of research, and firm size. As a result, they fail to explain how the R\&D free-rider problem was more readily overcome in the second and fourth phases. In future work, perhaps they will expand upon their suggestive observation that the early years of both expansionary phases coincided with business merger waves.

There are also problems with the general periodization of U.S. economic history that Duménil and Lévy propose. Their second phase, supposedly characterized by rising capital productivity and profitability, includes the Great Depression of the 1930s - during which both productivity and profitability plummeted to unprecedented lows. Duménil and Lévy recognize this prima facie contradiction and attempt to resolve it. They argue that the causes of the Great Depression were, on the one hand, lax regulation of growing financial activity, and on the other, a highly uneven diffusion of new technologies and organizational forms among competing firms that left the economy especially vulnerable to shocks. Because they believe productivity was steadily improving (albeit unevenly), the authors maintain that the Depression could have been averted had the government been more willing to reign in financial excess and encourage the adoption of cutting-edge industrial practices. However, Duménil and Lévy provide little evidence of unusual technological or organizational heterogeneity during the 1920s, and their data suggest that most of the productivity and profit rate gains posted during the period 1910-1950 occurred during World War II. A plausible alternative periodization would treat the Depression as the culmination of a single long phase of declining profitability that began in the last quarter of the $19^{\text {th }}$ century. ${ }^{4}$ The spectacular recovery of the early $1940 \mathrm{~s}$, premised on the substantial

${ }^{4}$ Duménil and Lévy themselves (1999a) once accepted such a periodization, but later dismissed it on questionable grounds (Duménil and Lévy 1992, 1993:Ch. 14). In their most detailed treatment of the issue (Duménil and Lévy 1992), they omitted the years 1930-45 from their data series altogether, apparently because the resulting truncated series proved a better fit with their hypothesis of a gradual improvement in productivity in the decades leading up to World War II!

Despite their different theoretical perspectives, both Shaikh (1992) and Arrighi (1994:215) treat the period from the late $19^{\text {th }}$ century through the $1930 \mathrm{~s}$ as one of deepening systemic crisis, though Shaikh's data begins in the 1890s and Arrighi's analysis is centered on Britain. Poletayev (1992) and $\mathrm{Li}, \mathrm{Xiao}$, and Zhu (2007) discern two full cycles of expansion and contraction between the 1870s and 1930s. Gordon, Edwards, and Reich (1982:41-7) propose a periodization similar to Duménil and Lévy's, based on data on growth rates.

On the dramatic increase in profit rates and productivity during World War II, compare Duménil, Glick and Lévy (1988) and (1993). The authors' analysis of the Great Depression is elaborated in much greater detail in Duménil and Lévy (1995b) and (1994). 
devaluation of capital that occurred during the 1930s and on a massive increase in military expenditure, would thus constitute an interregnum separating two long phases of declining profitability.

Duménil and Lévy's case for an emerging fourth phase, characterized by rising productivity and profit rates, is also debatable. They pass lightly over a substantial body of empirical research questioning whether recent productivity increases in the U.S. have diffused beyond a small subset of industries, and the extent to which information technology accounts for these increases (e.g. R. Gordon 2000). They offer no evidence in support of their contention that improvements in information technology are facilitating a reduction of managerial personnel, which is dubious in the U.S. case (D. Gordon 1996:Ch. 2). Furthermore, Duménil and Lévy's data reveal that the profit rate of the U.S. non-financial corporate sector has remained stagnant since the mid-1980s, once interest payments are taken into consideration. Although profit rates in the financial sector rose dramatically during the 1990s - enabling the rate of profit in the U.S. economy as a whole to recover over half of the ground lost since the mid-1960s - financial sector profits collapsed precipitously during the stock market decline of 2000-1, and they are once again being hammered by the crisis in the sub-prime mortgage market. ${ }^{5}$ Extrapolation from this turbulent trajectory is a hazardous undertaking.

Duménil and Lévy may also underestimate the centrality of worker exploitation to the late $20^{\text {th }}$ century recovery. They clearly recognize that a major corporate offensive took place during this period, in which unions were crushed, wages repressed, the welfare state gutted, and corporate taxes slashed. But Duménil and Lévy report that the profit share in the U.S. has increased by only about 10 percent over the past two decades. By contrast, economist Fred Moseley (1997) estimated that the rate of exploitation in the U.S. increased by about 35 percent between 1975 and 1994, and Simon Mohun (2005) found that by 2001 the rate of exploitation in the U.S. had increased some 50 percent compared to its 1964-1982 average. Duménil and Lévy's reliance on the conventional profit share measure, which elides the Marxian distinction between productive and unproductive labor, would seem to account for these discrepant results. ${ }^{6}$

${ }^{5}$ For the purposes of these comparisons, Duménil and Lévy use net worth, rather than fixed capital, in the denominator of the profit rate. This is important because, for the financial sector in particular, fixed capital is a poor measure of total capital invested. For further discussion, see Duménil and Lévy (2004a).

${ }^{6}$ Many Marxist economists have maintained that the labor of 'unproductive' workers - such as managers, advertising and sales personnel, financial sector workers, and civil servants - does not generate surplus value. Because unproductive workers must nevertheless be compensated, it follows that as the unproductive workforce grows relative to the productive workforce, the rate of exploitation of productive workers must increase in order to prevent a decline in the rate of profit. Several studies suggest that the unproductive share of the total workforce in the advanced economies grew substantially over the course of the $20^{\text {th }}$ century. On the distinction between productive and unproductive labor and its empirical application, the locus classicus is Gillman (1958:Ch.7); for more recent treatments, compare e.g. Gouverneur (1983), Freeman (1991), Mohun (2005), Moseley (1991, 1997), Shaikh and Tonak (1994), Smith (1993:Ch. 8), and Wolff (1987); for a critique of this literature, see Laibman (1992:Ch. 4). Though Duménil and Lévy do 
In support of their analysis of the recent U.S. experience, Duménil and Lévy can point to their data for the core European countries, which reveal a complete recovery of both profit rates and capital productivity from their low points in the mid-1980s. But the data also show a 50 percent increase in the profit share over the past two decades, which suggests that intensified worker exploitation was a critical dimension of the European recovery. And if the abovementioned erratic movements and sectoral divergences in the U.S. data give reason for pause, unfortunately the authors do not provide data on financial sector profitability for the European core as a whole, and their data for France cuts off just before the millennial stock market tumult. For a host of reasons then, it is difficult to know whether the productivity and profit rate gains experienced by the advanced economies over the past two decades represent the underpinnings of a new long phase of expansion or merely an interlude within the long downturn of the late $20^{\text {th }}$ century.

Much of Capital Resurgent is devoted to an analysis of the marked 'financialization' of the economy since the 1970s and the aggressive 'neoliberal' approach to economic policy that accompanied it. The authors see both of these phenomena as part and parcel of an attempt by the capitalist class as a whole to reassert its power over subordinate groups and reverse the trend of declining profit rates.

A key episode in this wider process was Federal Reserve chairman Paul Volcker's campaign of interest rate hikes, begun in late 1979 - which Duménil and Lévy dub 'the neoliberal coup.' Volcker's rate hikes, which helped provoke a deep recession, succeeded in achieving their primary goal of throttling inflation. This was a godsend to major creditors, whose interest income had been steadily devalued by rising prices during the 1970s. The U.S. government actively maintained relatively high real interest rates throughout the 1980s and most of the 1990s. Among the lasting domestic effects was mounting household indebtedness. Chief among the international repercussions was the debt crisis of the less-developed countries - which redounded to the benefit of U.S. corporations after the IMF and World Bank imposed 'structural adjustment' plans on bankrupt governments.

High interest rates, banking deregulation, and the development of asset price bubbles fueled the explosive growth of the financial sector. Throughout the 1990s, the profitability of financial corporations was roughly double that of their non-financial counterparts. As a result, investment in the financial sector increased dramatically: in 1980, the net worth of U.S. financial corporations was equivalent to roughly 14 percent of the net worth of non-financial corporations, but by century's end that proportion had reached well over 20 percent. Meanwhile, the distinction between the financial and non-financial sectors became blurrier, as non-financial corporations increasingly engaged in financial operations of their own, ranging from the extension of

not apply the distinction systematically here, they refer to it approvingly in passing (p.130-1); see also Duménil and Lévy (2003b).

On the whole, Capital Resurgent eschews direct engagement with competing Marxist perspectives. For the authors' critique of Brenner (1998), see Duménil and Lévy (1999b, 2002b), Duménil, Glick and Lévy (2001), and Brenner's (2002b) reply; on the 'regulation school,' see Duménil and Lévy (1999a); on the 'monopoly capital' approach associated with the journal Monthly Review, see Duménil and Lévy (1993:Ch.13) and Duménil, Glick and Rangel (1987); on the work of Mandel (e.g. 1978), see the sympathetic remarks in Duménil and Lévy (2001). 
consumer credit to speculative trading. In 1980, the value of U.S. non-financial corporations' financial assets was equivalent to about 45 percent of the value of their tangible assets, but twenty years later that ratio was 90 percent.

One of the authors' most provocative findings regarding 'financialization' is that the expansion of financial activity has retarded capital accumulation (the growth rate of the fixed capital stock). In both the U.S. and Europe, non-financial corporations' investment in plant and equipment continues to be funded overwhelmingly through profits generated by their own nonfinancial production activities. Very little capital invested in the financial sector is ultimately routed to the non-financial sector, and non-financial firms' own financial operations contribute virtually nothing to their productive capacity. In this respect, finance functions as a parasitic drain on the "real" economy.

There are several weaknesses in Duménil and Lévy's account of financialization. One is terminological: they use the word 'finance' somewhat loosely, sometimes to refer to the financial sector, elsewhere to denote the capitalist class. A second weakness, which is compounded by the first, involves cavalier attributions of agency such as the following (p.77): "Finance decided to stop inflation in order to protect its revenues and investments, whatever the cost might be for others." Since the authors acknowledge that a substantial swathe of the financial sector - most notably the savings and loans - suffered crippling losses as a direct result of the Federal Reserve's interest rate hikes, the suggestion that the 'neoliberal coup' was the work of 'finance' seems like an oversimplification. William Greider's (1989) depiction of a motley of conservative bankers and economists at the Fed reacting to conflicting pressures and unforeseen events is a useful corrective here.

Building on their analysis of the past, Duménil and Lévy draw attention to both dangers and opportunities that lie ahead. Rising productivity opens up the possibility of sustained profitability and growth. But in the absence of a politically powerful opposition to the capitalist class, the rich will continue to reap most of the benefits of future prosperity. If financialization continues, it will slow the pace of capital accumulation, to the detriment of output and employment. More ominously, if financial activity is not brought to heel, the economy will remain vulnerable to violent crises, regardless of otherwise favorable trends in productivity and profits.

Nevertheless, the authors believe that with adequate government regulation, serious crises can be averted in the coming period - a conclusion consistent with their account of the Great Depression. Despite their evident hostility toward capitalists and capitalism, they end the book on a decidedly moderate note, describing Keynesian reform as "the only alternative to a more radical road - that of real socialism and social-democratic alternatives - that we have known for decades to have gone wrong, everywhere" (p.204). If by 'real socialism' Duménil and Lévy are referring to the undemocratic centrally-planned economies of the Soviet type, their negative judgment is warranted. But with tens of millions of Americans lacking health care, paid parental leave, and many other state-guaranteed benefits currently enjoyed by their European counterparts, we should not concede the failure of social democracy so readily. In any event, do social democracy and Stalinism really exhaust the range of conceivable radical alternatives to neoliberal capitalism?

Contributing to the authors' pessimism regarding alternatives is a particular view of the development of class relations over the past century, according to which the most persistent challenge to the capitalist class in the developed economies has come from managers and 


\section{JOURNAL OF WORLD-SYSTEMS RESEARCH}

technocrats. ${ }^{7}$ Neoliberalism, seen from this perspective, represents the attempt by a weakened capitalist class to re-assert control over a rising managerial elite. This is a distorted picture, and it rests on some questionable historical judgments, such as the authors' claim that managers constituted a critical base of support for the New Deal.

Despite my reservations and criticisms, Capital Resurgent is a major leftist intervention into debates over the past and future of capitalism. Duménil and Lévy have attempted a bold synthesis of economic theory and history that deserves to be widely read and discussed.

\section{REFERENCES}

Armstrong, Philip, Andrew Glyn, and John Harrison. 1991. Capitalism since 1945. Cambridge: Blackwell.

Arrighi, Giovanni. 1994. The Long Twentieth Century: Money, Power, and the Origins of Our Times. New York: Verso.

Arrow, Kenneth J. 1959. "Economic Welfare and the Allocation of Resources for Invention." P1856-RC. Santa Monica: RAND Corporation.

Berle, Jr., Adolph A. and Gardiner C. Means. 1933 [1932]. The Modern Corporation and Private Property. New York: Macmillan.

Brenner, Robert. 1998. "The Economics of Global Turbulence: A Special Report on the World Economy, 1950-98." New Left Review 229:i-265. . 2002a. The Boom and the Bubble: The US in the World Economy. New York: Verso.

_ 2002b. "The Trajectory of the Manufacturing Profit Rate: A Reply to Duménil and Lévy." Review of Radical Political Economics 34:49-56.

Burnham, James. 1941. The Managerial Revolution: What is Happening in the World. New York: John Day.

Chan-Lee, James H. and Helen Sutch. 1985. "Profits and Rates of Return in OECD Countries." Economics and Statistics Department Working Papers No. 20. Paris: Organization for Economic Cooperation and Development.

Chandler, Jr., Alfred D. 1971. The Visible Hand: The Managerial Revolution in American Business. Cambridge: Harvard University Press.

${ }^{7}$ Though this analysis bears resemblance to ideas advanced by Berle and Means (1933), Burnham (1941) and Galbraith (1967), Duménil and Lévy's views are distinctive in several respects. They assert that managerial ascendance was facilitated by a political alliance with the working class: managers and workers together imposed a 'Keynesian compromise' on capitalists during the middle third of the twentieth century. They also stress that the capitalist class retained a distinct identity and a significant degree of power notwithstanding this compromise. By contrast, in the Soviet Union capitalists were thoroughly dispossessed and managers rose to the position of ruling class. Duménil and Lévy clarify their relationship to prior scholarship on the 'managerial revolution' in their (2001), (2002c) and (2005). Their interpretation of the Soviet and Chinese experiences is developed in several French-language writings (e.g. Duménil and Lévy 1998). In Duménil and Lévy (2004b), the authors conclude that the U.S. capitalist class has won the top tier of managers over to the neoliberal project by granting them lucrative retirement packages composed of financial assets. 
Duménil, Gérard. 1983-4. "Beyond the Transformation Riddle: A Labor Theory of Value." Science and Society 47:427-50.

Duménil, Gérard, Mark Glick, and Dominique Lévy. 1988. "Long-Term Trends in Profitability: The Recovery of World War II." Jerome Levy Institute Working Paper No. 10. Annandale-on-Hudson, NY: The Jerome Levy Economics Institute. http://papers.ssrn.com/sol3/papers.cfm?abstract_id=191372.

1993. "The Rise of the Rate of Profit During World War II." Review of Economics and Statistics 75(2):315-20.

. 2001. "Brenner on Competition." Capital and Class 74:61-77.

Duménil, Gérard, Mark Glick, and Jose Rangel. 1987. "Theories of the Great Depression: Why Did Profitability Matter?” Review of Radical Political Economics 19(2):16-42.

Duménil, Gérard and Dominique Lévy. 1989. "Labor Values and the Imputation of Labor Contents." Metroeconomica 40:159-78.

1992. "Stages in the Development of US Capitalism: Trends in Profitability and Technology since the Civil War." Pp. 42-65 in International Perspectives on Profitability and Accumulation, edited by Fred Moseley and Edward N. Wolff. Brookfield, VT: Edward Elgar.

1993. The Economics of the Profit Rate: Competition, Crises and Historical Tendencies in Capitalism. Brookfield, VT: Edward Elgar.

1994. "Stylized Facts about Technical Progress Since the Civil War: A Vintage Model." Structural Change and Economic Dynamics 5(1):1-23.

1995a. "A Stochastic Model of Technical Change: An Application to the US Economy (1869-1989)." Metroeconomica 46:213-45.

1995b. "The Great Depression: A Paradoxical Event?" Unpublished manuscript. Paris: CEPREMAP. http://cepremap.ens.fr/ levy/.

. 1998. Au-delà du Capitalisme? Paris: Presses Universitaires de France.

. 1999a [1990]. "The Regulation School in Light of One Century of the U.S. Economy." Unpublished manuscript. Paris: CEPREMAP. http://cepremap.ens.fr/ levy/.

. 1999b. "Brenner on Distribution." Historical Materialism 4:73-94.

. 2000. "The Conservation of Value: A Rejoinder to Alan Freeman." Review of Radical Political Economics 32(1):119-46.

. 2001. "Periodizing Capitalism: Technology, Institutions and Relations of Production." Pp.

141-162 in Phases of Capitalist Development: Booms, Crises and Globalizations, edited by Robert Albritton, Makoto Itoh, Richard Westra, and Alan Zuege. New York: Palgrave. . 2002a. "The Profit Rate: Where and How Much Did it Fall? Did it Recover? (USA 19482000)." Review of Radical Political Economics 34:437-61.

2002b. "Manufacturing and Global Turbulence: Brenner's Misinterpretation of Profit Rate Differentials." Review of Radical Political Economics 34:45-8.

. 2002c. "The Nature and Contradictions of Neoliberalism." Pp. 43-72 in A World of Contradictions: Socialist Register 2002, edited by Leo Panitch and Colin Leys. New York: Monthly Review Press.

. 2003a. "Technology and Distribution: Historical Trajectories à la Marx." Journal of Economic Behavior and Organization 52:201-33. 
. 2003b. "Production and Management: Marx's Dual Theory of Labor." Pp. 137-157 in Value and the World Economy Today: Production, Finance and Globalization, edited by Richard Westra and Alan Zuege. London: Palgrave.

. 2004a. "The Real and Financial Components of Profitability (United States, 1952-2000)." Review of Radical Political Economics 36:82-110.

. 2004b. "Neoliberal Income Trends." New Left Review 30:105-133.

. 2005. "Costs and Benefits of Neoliberalism: A Class Analysis." Pp. 17-45 in Financialization and the World Economy, edited by Gerald Epstein. Northampton, MA: Edward Elgar.

Freeman, Alan. 1991. "National Accounts in Value Terms: The Social Wage and the Profit Rate in Britain, 1950-1986." pp. 84-106 in Quantitative Marxism, edited by Paul Dunne. Cambridge: Polity.

Galbraith, John K. 1967. The New Industrial State. Boston: Houghton Mifflin.

Gillman, Joseph M. 1958. The Falling Rate of Profit: Marx's Law and its Significance to Twentieth-Century Capitalism. New York: Cameron Associates.

Gordon, David M. 1996. Fat and Mean: The Corporate Squeeze of Working Americans and the Myth of Managerial "Downsizing." New York: Free Press.

Gordon, David M., Richard Edwards, and Michael Reich. 1982. Segmented Work, Divided Workers: The Historical Transformation of Labor in the United States. New York: Cambridge University.

Gordon, Robert J. 2000. "Does the New Economy Measure Up to the Great Inventions of the Past?" Journal of Economic Perspectives 14(4):49-74.

Gouverneur, Jacques. 1983. Contemporary Capitalism and Marxist Economics. Totowa, NJ: Barnes and Noble.

Greider, William. 1989 [1987]. Secrets of the Temple: How the Federal Reserve Runs the Country. New York: Simon and Schuster.

Kliman, Andrew J. 1996. "A Value-Theoretic Critique of the Okishio Theorem." Pp. 206-224 in Marx and Non-equilibrium Economics, edited by Alan Freeman and Guglielmo Carchedi. Brookfield, VT: Edward Elgar.

Laibman, David. 1992. Value, Technical Change, and Crisis: Explorations in Marxist Economic Theory. Armonk, NY: M. E. Sharpe.

Li, Minqi, Feng Xiao, and Andong Zhu. 2007. "Long Waves, Institutional Changes, and Historical Trends: A Study of the Long-Term Movement of the Profit Rate in the Capitalist World-Economy." Journal of World-Systems Research 13(1):33-54.

Mandel, Ernest. 1978 [1975]. Late Capitalism. London: Verso.

Mohun, Simon. 2005. "On Measuring the Wealth of Nations: The US Economy, 1964-2001." Cambridge Journal of Economics 29:799-815.

Moseley, Fred. 1991. The Falling Rate of Profit in the Postwar United States Economy. New York: St. Martin's.

. 1997. "The Rate of Profit and the Future of Capitalism." Review of Radical Political Economics 29(4):23-41.

Poletayev, Andrey V. 1992. "Long Waves in Profit Rates in Four Countries." Pp. 151-168 in New Findings in Long-Wave Research, edited by Alfred Kleinknecht, Ernest Mandel, and Immanuel Wallerstein. New York: St. Martin's. 
Shaikh, Anwar. 1978. "An Introduction to the History of Crisis Theories." Pp. 219-241 in U.S. Capitalism in Crisis, edited by Bruce Steinberg, et al. New York: Union for Radical Political Economics.

. 1992. "The Falling Rate of Profit as the Cause of Long Waves: Theory and Empirical Evidence." Pp. 174-195 in New Findings in Long-Wave Research, edited by Alfred Kleinknecht, Ernest Mandel, and Immanuel Wallerstein. New York: St. Martin's. . 1999. "Explaining the Global Economic Crisis." Historical Materialism 5:103-44.

Shaikh, Anwar M. and E. Ahmet Tonak. 1994. Measuring the Wealth of Nations. Cambridge: Cambridge University.

Smith, Murray E. G. 1994. Invisible Leviathan: The Marxist Critique of Market Despotism Beyond Postmodernism. Toronto: University of Toronto.

United States Patent and Trademark Office. 2008. "U.S. Patent Activity, Calendar Years 1790 to the Present." http://www.uspto.gov/web/offices/ac/ido/oeip/taf/h_counts.htm.

Webber, Michael J. and David L. Rigby. 1996. The Golden Age Illusion: Rethinking Postwar Capitalism. New York: Guilford.

Weisskopf, Thomas E. 1992. "A Comparative Analysis of Profitability Trends in the Advanced Capitalist Economies." Pp. 13-41 in International Perspectives on Profitability and Accumulation, edited by Fred Moseley and Edward N. Wolff. Brookfield, VT: Edward Elgar.

Wolff, Edward N. 1987. Growth, Accumulation, and Unproductive Activity: An Analysis of the Postwar U.S. Economy. New York: Cambridge.

. 2003. "What's Behind the Rise in Profitability in the US in the 1980s and 1990s?" Cambridge Journal of Economics 27:479-99. 